\title{
Influence of Cutting Height and Gliricidia Green Leaf Manure Application (GLM) on Different Crops under Alley Cropping System
}

\author{
K. R. Ramesh ${ }^{1}$, H. K. Deshmukh ${ }^{2} *$, V. J. Rathod ${ }^{3}$, \\ N. Kowshika ${ }^{2}$, M. Kiruba ${ }^{1}$ and S. Bavish ${ }^{1}$ \\ ${ }^{1}$ Forestry College and Research Institute, Tamil Nadu Agril University, Mettupalam, India \\ ${ }^{2}$ Dr. Panjabrao Deshmukh Krishi Vidyapeeth, Akola, Maharashtra, India \\ *Corresponding author
}

A B S T R A C T

\section{Keywords}

Cutting height, green leaf manure, alley cropping and dry matter

Article Info

Accepted:

18 May 2020

Available Online:

10 June 2020
Agriculture at present focuses on crop productivity with a balance on soil health. In dryland areas application of green leaf manures in addition to the regular dose of fertilizers, which proves to ensure soil health and cost economics without affecting the yield parameter. Gliricidia based alley cropping with Ragi, Barnyard millet and Groundnut intercrops was experimented to understand the influence of Gliricidia GLM application on the intercrops. The resultant of incorporating gliricidia green leaf manure into the soil was found to increase the yield of intercrops than the mulching technique, which would help the dryland farmers to increase productivity.

\section{Introduction}

Agriculture in drylands is still a cumbersome task to be fulfilled in order to enhance the agrarian production. Soil health and crop productivity are the targets of present agricultural sector which can be ensured through crop residue recycling, farm yard manure, biofertilizers, inclusion of legumes as intercrops, green manure crops, green leaf manuring, tank silt addition, vermicoposting etc. (Srinivasarao et al., 2011 a,c). Organic manuring tends to improve soil physical properties (Mc Rae and Mehuys, 1988) where green manuring proves to be important (Meisheri et al., 2001) In this aspect, incorporating Gliricidia which is fast growing, tropical nature and a leguminous tree would provide potential benefit to the farmers.

Wani et al., (2009) were able to prove that Gliricidia sepium on farm bunds was able to provide $28-30 \mathrm{~kg} / \mathrm{ha}$ of Nitrogen annually in addition to Organic matter. The gliricidia leaf manure application of $1 \mathrm{t} / \mathrm{ha}$ would be able to 
provide $21 \mathrm{~kg} \mathrm{~N}, 2.5 \mathrm{~kg} \mathrm{P}, 18 \mathrm{~kg} \mathrm{~K}, 85 \mathrm{~g} \mathrm{Zn}$, $164 \mathrm{~g} \mathrm{Mn}, 365 \mathrm{~g} \mathrm{Cu}, 728 \mathrm{~g} \mathrm{Fe}$ in conjunction with considerable amounts of $\mathrm{Mo}, \mathrm{B}, \mathrm{Mg}, \mathrm{Ca}$, $\mathrm{S}$ etc. Gliricidia is good source of $\mathrm{N}(2.76 \%)$ and $\mathrm{K} \quad(4.6 \%) \quad$ nutrients (http://agritech.tnau.ac.in). Sharma et al., (2004) found that the treatment $2 t$ gliricidia loppings $+20 \mathrm{~kg} \mathrm{~N}$ increased the sorghum yield by 84.6 per cent. This article tends to understand the influence of cutting height and different methods of Gliricidia Green Leaf Manure (GLM) application on the growth and yield of Ragi, Barnyard millet and Groundnut intercrops.

\section{Materials and Methods}

\section{Study area}

The given study about gliricidia alley cropping was conducted in Agricultural Research Station, Chettinad during July 2017 to June 2019 period. The gliricidia tree species was chosen as the green leaf manure source. Three crops species viz., Ragi, Barnyard Millet and Groundnut were intercropped for the study. The interaction performance was studied and plant height, No. of tillers (Root length in case of Groundnut), Dry weight, Grain yield (Pod yield in case Groundnut) was recorded. Experiments were laid out in replicated factorial randomised block design with four replications and comprising 12 treatment combination with two cutting heights $(1 \mathrm{~m}$ from ground and $1.5 \mathrm{~m}$ from ground), two Green Leaf Manure Application (GLM application with soil incorporation and GLM application with surface application) and three intercrops (Ragi, Barnyard Millet and Groundnut).

\section{Results and Discussion}

The influence of cutting height and method of application of Gliricidia GLM on growth and yield of Ragi in Gliricidia based alley cropping is given in Table 1 and Figure 1.Cutting of Gliricidia hedges at various height i.e., $1 \mathrm{~m}$ and $1.5 \mathrm{~m}$ above ground level plays less significant influence on plant height of intercrop Ragi. Application of Gliricidia Green Leaf Manure (GLM) invarious methods i.e., surface application as mulch and soil incorporation plays high significant influence on plant height, Dry Matter Production and yield of intercrop. The interaction between cutting height and method of application of GLM does not have much influence on growth and yield of intercrop. The cutting of Gliricidia hedges at $1 \mathrm{~m}$ above Ground level and applied as GLM by Soil incorporation increase the plant growth and yield followed by cutting at $1.5 \mathrm{~m}$ height and applied as mulch cover control. The usage of Gliricidia amendments produced higher yields in of Ragi crop with reference to a research conducted by Anchal Dass et al., (2013).

In case of Barnyard millet (Table 2 and Figure 2), the cutting of Gliricidia hedges at various heights does not have significant variation in plant growth and yield of intercrop. Application of Gliricidia as GLM in various methods viz., surface application and soil incorporation shows significant variation among the growth and Barnyard millet. Cutting of Gliricidia at $1 \mathrm{~m}$ above level and application of Gliricidia GLM as soil incorporation shows higher DMP and yield in Barnyard millet. The interaction between cutting height and method of application did not show any variation in growth and yield of Barnyard millet. Similar results were observed by Suguna and Swaminathan (2012) while incorporating Pongamia pinnata Green Leaf manure on yield of Barnyard millet where $2000 \mathrm{~kg} / \mathrm{ha}$ leaf incorporation of Pongamia with 45 days of decomposition period increased the yield to $1216 \mathrm{~kg} / \mathrm{ha}$ against the $861 \mathrm{~kg} / \mathrm{ha}$ from zero input management. 
Table.1 Influence of cutting height and method of application of Gliricidia GLM on growth and yield of Ragi in Gliricidia based alley cropping

\begin{tabular}{|c|c|c|c|c|c|c|c|c|c|c|c|c|}
\hline Treatments & \multicolumn{3}{|c|}{ Plant height (cm) } & \multicolumn{3}{|c|}{ No. of tillers } & \multicolumn{3}{|c|}{$\begin{array}{c}\text { Dry weight DMP } \\
\text { (kg/ha) }\end{array}$} & \multicolumn{3}{|c|}{$\begin{array}{l}\text { Grain yield } \\
\text { (kg/ha) }\end{array}$} \\
\hline Control & \multicolumn{3}{|c|}{60} & \multicolumn{3}{|c|}{2} & \multicolumn{3}{|c|}{1008} & \multicolumn{3}{|c|}{300} \\
\hline H1A1 & \multicolumn{3}{|c|}{63.6} & \multicolumn{3}{|c|}{2.4} & \multicolumn{3}{|c|}{1032} & \multicolumn{3}{|c|}{336} \\
\hline H1A2 & \multicolumn{3}{|c|}{69.2} & \multicolumn{3}{|c|}{2.8} & \multicolumn{3}{|c|}{1144} & \multicolumn{3}{|c|}{376} \\
\hline H2A1 & \multicolumn{3}{|c|}{62} & \multicolumn{3}{|c|}{1.8} & \multicolumn{3}{|c|}{1016} & \multicolumn{3}{|c|}{312} \\
\hline H2A2 & \multicolumn{3}{|c|}{68.2} & \multicolumn{3}{|c|}{2.4} & \multicolumn{3}{|c|}{1136} & \multicolumn{3}{|c|}{364} \\
\hline \multirow[t]{2}{*}{ Mean } & \multicolumn{3}{|c|}{64.6} & \multicolumn{3}{|c|}{2.28} & \multicolumn{3}{|c|}{1067.2} & \multicolumn{3}{|c|}{337.6} \\
\hline & SED & $\mathrm{CD}$ & & SED & $\mathrm{CD}$ & & SED & $\mathrm{CD}$ & & SED & $\mathrm{CD}$ & \\
\hline H & 0.37 & 0.80 & NS & 0.32 & 0.69 & $* *$ & 12.33 & 26.86 & $*$ & 10.1 & 21.9 & NS \\
\hline $\mathbf{A}$ & 0.37 & 0.80 & $* *$ & 0.32 & 0.69 & $* *$ & 12.33 & 26.86 & $* *$ & 10.1 & 21.9 & $* *$ \\
\hline HA & 0.52 & 1.13 & NS & 0.45 & 0.97 & NS & 17.44 & 37.99 & NS & 14.2 & 31.0 & NS \\
\hline \multicolumn{7}{|c|}{ H1- Cutting height at 1m above GL } & \multicolumn{6}{|c|}{ A1- Surface application of Glyricidia GLM } \\
\hline \multicolumn{7}{|c|}{ H2- Cutting of Glyricidia at $1.5 \mathrm{~m}$ above GL } & \multicolumn{6}{|c|}{ A2- Soil incorporation of Glyricidia GLM } \\
\hline
\end{tabular}

Table.2 Influence of cutting height and method of application of Gliricidia GLM on growth and yield of Barnyard millet in Gliricidia based alley cropping

\begin{tabular}{|c|c|c|c|c|c|c|c|c|c|c|c|c|}
\hline Treatments & \multicolumn{3}{|c|}{ Plant height (cm) } & \multicolumn{3}{|c|}{ No. of tillers } & \multicolumn{3}{|c|}{$\begin{array}{c}\text { Dry weight DMP } \\
\text { (kg/ha) }\end{array}$} & \multicolumn{3}{|c|}{$\begin{array}{l}\text { Grain yield } \\
\text { (kg/ha) }\end{array}$} \\
\hline Control & \multicolumn{3}{|c|}{57} & \multicolumn{3}{|c|}{2} & \multicolumn{3}{|c|}{840} & \multicolumn{3}{|c|}{520} \\
\hline H1A1 & \multicolumn{3}{|c|}{57.2} & \multicolumn{3}{|c|}{24} & \multicolumn{3}{|c|}{848} & \multicolumn{3}{|c|}{556} \\
\hline H1A2 & \multicolumn{3}{|c|}{64} & \multicolumn{3}{|c|}{3.2} & \multicolumn{3}{|c|}{896} & \multicolumn{3}{|c|}{584} \\
\hline H2A1 & \multicolumn{3}{|c|}{56.4} & \multicolumn{3}{|c|}{2.2} & \multicolumn{3}{|c|}{824} & \multicolumn{3}{|c|}{536} \\
\hline H2A2 & \multicolumn{3}{|c|}{63} & \multicolumn{3}{|c|}{3} & \multicolumn{3}{|c|}{872} & \multicolumn{3}{|c|}{580} \\
\hline Mean & \multicolumn{3}{|c|}{59.52} & \multicolumn{3}{|c|}{6.88} & \multicolumn{3}{|c|}{856} & \multicolumn{3}{|c|}{555.2} \\
\hline & SED & $\mathrm{CD}$ & & SED & $\mathrm{CD}$ & & SED & $\mathrm{CD}$ & & SED & $\mathrm{CD}$ & \\
\hline $\mathbf{H}$ & 0.58 & 1.26 & NS & 0.19 & 0.41 & NS & 11.55 & 25.16 & NS & 6.43 & 14.0 & NS \\
\hline $\mathbf{A}$ & 0.58 & 1.26 & $* *$ & 0.19 & 0.41 & $* *$ & 11.55 & 25.16 & $* *$ & 6.43 & 14.0 & $* *$ \\
\hline HA & 0.82 & 1.79 & NS & 0.26 & 0.58 & NS & 16.33 & 35.58 & NS & 9.09 & 19.81 & NS \\
\hline \multicolumn{7}{|c|}{ H1- Cutting height at 1m above GL } & \multicolumn{6}{|c|}{ A1- Surface application of Glyricidia GLM } \\
\hline \multicolumn{7}{|c|}{ H2- Cutting of Glyricidia at $1.5 \mathrm{~m}$ above GL } & \multicolumn{6}{|c|}{ A2- Soil incorporation of Glyricidia GLM } \\
\hline
\end{tabular}


Table.3 Influence of cutting height and method of application of Gliricidia GLM on growth and yield of Groundnut in Gliricidia based alley cropping

\begin{tabular}{|c|c|c|c|c|c|c|c|c|c|c|c|c|}
\hline Treatments & \multicolumn{3}{|c|}{ Plant height (cm) } & \multicolumn{3}{|c|}{ Root length (cm) } & \multicolumn{3}{|c|}{$\begin{array}{c}\text { Dry weight DMP } \\
\text { (kg/ha) }\end{array}$} & \multicolumn{3}{|c|}{ Pod yield (kg/ha) } \\
\hline Control & \multicolumn{3}{|c|}{16} & \multicolumn{3}{|c|}{11} & \multicolumn{3}{|c|}{1080} & \multicolumn{3}{|c|}{840} \\
\hline H1A1 & \multicolumn{3}{|c|}{17} & \multicolumn{3}{|c|}{11.4} & \multicolumn{3}{|c|}{1112} & \multicolumn{3}{|c|}{832} \\
\hline H1A2 & \multicolumn{3}{|c|}{19.2} & \multicolumn{3}{|c|}{12.6} & \multicolumn{3}{|c|}{1184} & \multicolumn{3}{|c|}{904} \\
\hline H2A1 & \multicolumn{3}{|c|}{17.4} & \multicolumn{3}{|c|}{9.8} & \multicolumn{3}{|c|}{1096} & \multicolumn{3}{|c|}{824} \\
\hline H2A2 & \multicolumn{3}{|c|}{18.8} & \multicolumn{3}{|c|}{12} & \multicolumn{3}{|c|}{1136} & \multicolumn{3}{|c|}{888} \\
\hline Mean & \multicolumn{3}{|c|}{17.68} & \multicolumn{3}{|c|}{11.36} & \multicolumn{3}{|c|}{1121.6} & \multicolumn{3}{|c|}{857.6} \\
\hline & SED & $\mathrm{CD}$ & & SED & $\mathrm{CD}$ & & SED & $\mathrm{CD}$ & & SED & $\mathrm{CD}$ & \\
\hline $\mathbf{H}$ & 0.37 & 0.80 & NS & 0.32 & 0.69 & $* *$ & 12.33 & 26.86 & $*$ & 10.1 & 21.9 & NS \\
\hline $\mathbf{A}$ & 0.37 & 0.80 & $* *$ & 0.32 & 0.69 & $* *$ & 12.33 & 26.86 & $* *$ & 10.1 & 21.9 & $* *$ \\
\hline HA & 0.52 & 1.13 & NS & 0.45 & 0.97 & NS & 17.44 & 37.99 & NS & 14.2 & 31.0 & NS \\
\hline \multicolumn{7}{|c|}{ H1- Cutting height at $1 \mathrm{~m}$ above GL } & \multicolumn{6}{|c|}{ A1- Surface application of Glyricidia GLM } \\
\hline \multicolumn{7}{|c|}{ H2- Cutting of Glyricidia at $1.5 \mathrm{~m}$ above GL } & \multicolumn{6}{|c|}{ A2- Soil incorporation of Glyricidia GLM } \\
\hline
\end{tabular}

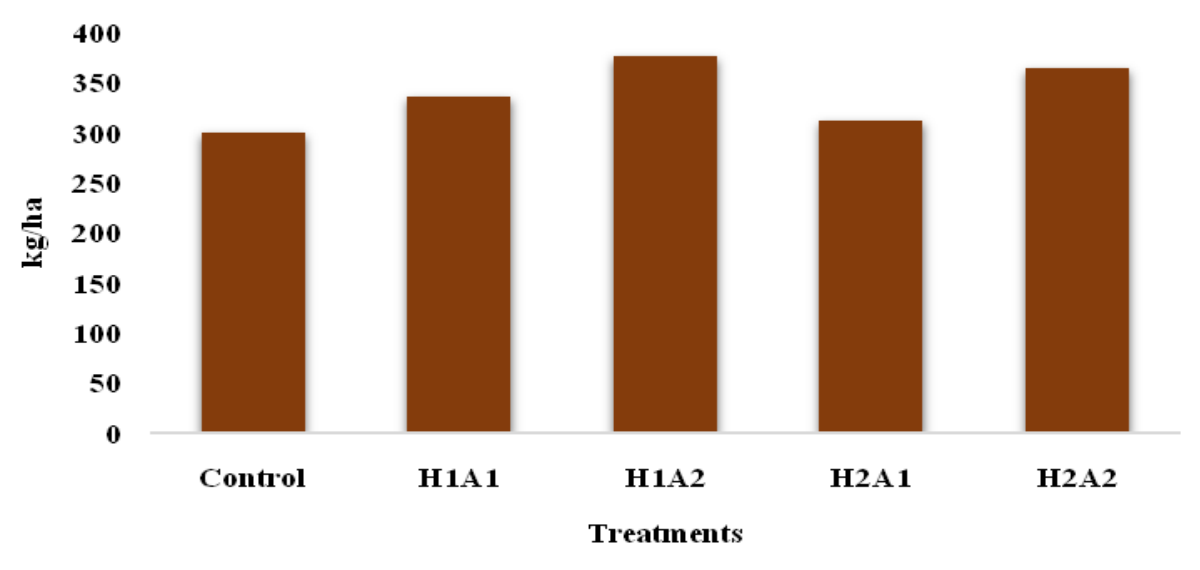

Fig.1 Ragi Grain Yield (kg/ha)

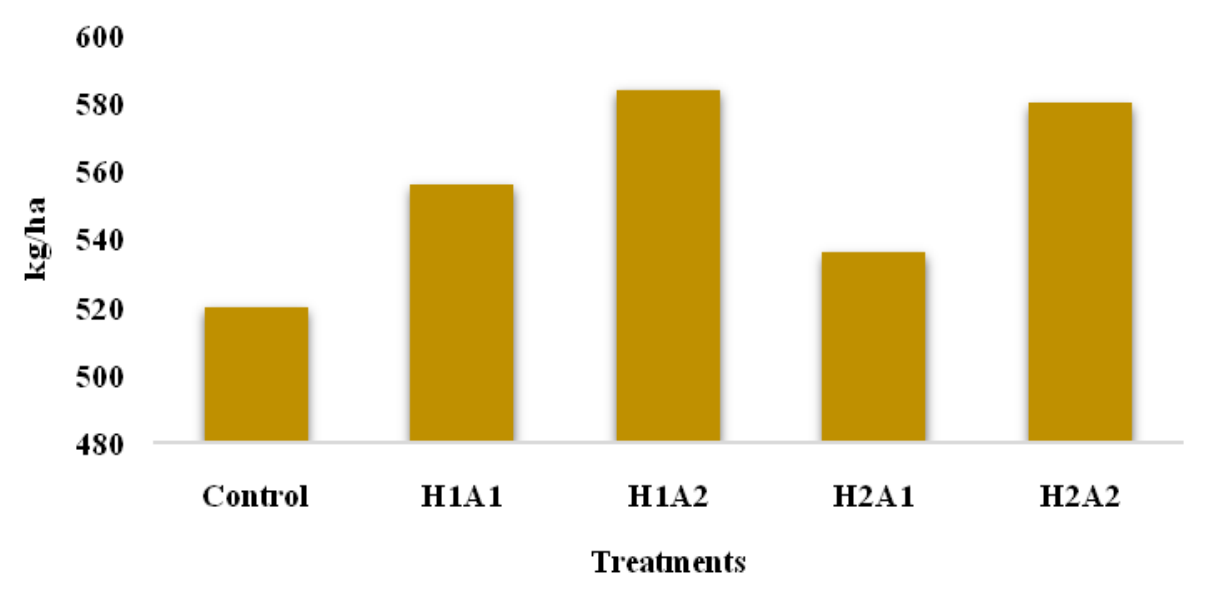

Fig.2 Barnyard millet Grain Yield (kg/ha) 


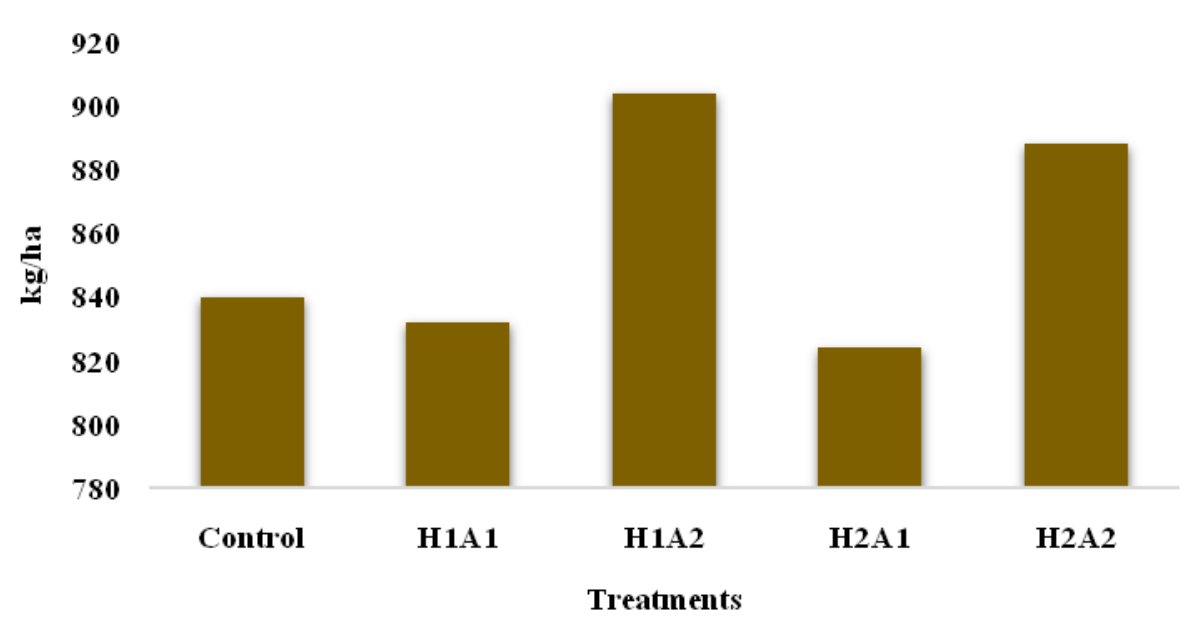

Fig.3 Groundnut Pod yield (kg/ha)

The influence Gliricidia GLM on growth and yield of groundnut is given in Table 3 and Figure 4. There is a less significant variation in Root length and DMP of Groundnut due to various level of cuttings of Gliricidia hedges i.e., at $1 \mathrm{~m}$ and $1.5 \mathrm{~m}$ above ground level.

Significant variation was found in plant height, Root length, DMP and Pod yield of Groundnut due to various methods of application of Gliricidia GLM as surface application and soil incorporation. Among the various treatments cutting of Gliricidia at $1 \mathrm{~m}$ above GL and application of Gliricidia GLM as soil incorporation shows higher plant growth and pod yield in Groundnut under Gliricidia based alley cropping system. Schroth et al., (1995) have evidenced that agroforestry with Gliricidia would potentially increase the yield of groundnut by reducing transpiration and crop diseases in drought years.

The cutting height and method of application of gliricidia green leaf manure has differential influence on the three intercrops being chosen. On the whole, cutting of gliricidia hedges at $1 \mathrm{~m}$ above the ground level and soil incorporation of the same as a green leaf manure was found to be more successful in increasing the growth and yield of Ragi,
Barnyard millet and Groundnut compared to all other treatments. The application of gliricidia green leaf manure would be beneficial as a source of Nitrogen for leaf growth and Potassium for strengthening the source-sink relationship.

\section{References}

Anchal Dass, Sudhishri, S., and Lenka, N. K. 2013. Integrated Nutrient Management to Improve Finger Millet Productivity and Soil Conditions in Hilly Region of Eastern India. Journal of Crop Management, 27(5):528-546.

http://agritech.tnau.ac.in/org_farm/orgfarm_gr een\%20manure.html

Meisheri. T. G., Usadadia. V. P., Vaidya A. C. and Patel J. B. 2001. Green Manures. Indian farming. 11- 12.

McRae, R.J., Mehuys, G.R. 1988. The effect of green manuring on the physical properties of temperate-area soils. $A d v$. Soil Sci., 3: 71-94.

Schroth, G., Balle, P., and Peltier, R. 1995. Alley cropping groundnut with Gliricidia sepium in Côte d'Ivoire: effects on yields, microclimate and crop diseases. Agroforestry Systems, 29: 147163.

Sharma, K.L., Mandal, U. K., Srinivas, 
K.,Vittal, K.P.R., Mandal, B., Kusuma Grace, J. and Ramesh, V. 2004. Longterm soil management effects on crop yields and soil quality in a dryland Alfisol. Soil and Tillage Research, 83 (2): 246-259.

Srinivasa Rao, Ch., Venkateswarlu, B., Dinesh Babu, M., Wani, S.P., Dixit, S, Sahrawat, K.L. and Sumanta Kundu.2011. Soil Health Improvement with Gliricidia Green Leaf Manuring in Rainfed Agriculture, On Farm Experiences. Central Research Institute for Dryland Agriculture, Santoshnagar, P.O. Saidabad, Hyderabad 500 059, Andhra Pradesh, 16p.

Srinivasarao, Ch., Venkateswarlu, B., Sreenath Dixit, Sumanta Kundu and Gayatri Devi, K. 2011. Livelihood Impacts of Soil Health Improvement in Backward and Tribal Districts of Andhra Pradesh. Central Research Institute for Dryland Agriculture, Hyderabad, Andhra Pradesh, India, 119p..
Srinivasarao, Ch., Venkateswarlu, B., Lal, R., Singh, A.K., Sumanta Kundu, Vittal, K.P.R., Patel, J.J. and Patel, M.M. 2011. Long-term manuring and fertilizer effects on depletion of soil organic carbon stocks under pearl millet-cluster beancastor rotation in western India. Land Degradation and Development, DOI: 10.1009/dp 1158.

Suguna, A., and Swaminathan, C. 2012. Influence of Pongamia pinnata Green Leaf Manure on Growth and Yield of Brnyard millet (Echinochloa frumentaceae L.). Madras Agric.J., 99 (Special Issue): 72-73.

Wani S.P., Sreedevi T.K., Rockström J. and Ramakrishna Y.S.. 2009.Rainfed Agriculture - Past trend and future prospectus. In: Wani SP, Rockström $\mathbf{J}$ and Oweis $\mathrm{T}$ (eds) Rainfed agriculture: Unlocking the Potential. Comprehensive Assessment of Water Management in Agriculture Series. CAB International, Wallingford, UK, 1$35 \mathrm{p}$.

\section{How to cite this article:}

Ramesh. K. R., H. K. Deshmukh, V. J. Rathod, N. Kowshika, M. Kiruba and Bavish. S. 2020. Influence of Cutting Height and Gliricidia Green Leaf Manure Application (GLM) on Different Crops under Alley Cropping System. Int.J.Curr.Microbiol.App.Sci. 9(06): 1790-1795. doi: https://doi.org/10.20546/ijcmas.2020.906.223 